\title{
Perjalanan \& Prospek Produk Herbal di Indonesia
}

\author{
Rachmat Sarwono \\ Founder \& CEO Borobudur Natural Herbal Industry
}

Obat Tradisional adalah bahan atau ramuan bahan yang berupa bahan tumbuhan, bahan hewan, bahan mineral, sediaan sarian (galenik) atau campuran dari bahan tersebut yang secara turun temurun telah digunakan untuk pengobatan, dan dapat diterapkan sesuai dengan norma yang berlaku di masyarakat. Sekarang ini, obat tradisional atau lebih dikenal sebagai Jamu/Herbal sudah banyak berinovasi dari berbagai aspek seperti grade (Jamu, Obat Herbal Terstandard, Fitofarmaka), klaim khasiat, proses produksi, teknologi yang digunakan, hingga bentuk sediaan yang lebih praktis untuk dikonsumsi seperti kapsul, pil, kaplet, cairan obat dalam dll.

Industri Jamu Borobudur telah menerapkan CPOTB/GMP dan menggunakan mesin-mesin modern buatan Jerman yang sangat mendukung dalam proses produksi sehingga menghasilkan produk yang berkualitas dan memenuhi persyaratan yang telah ditetapkan. Disamping itu penggunaan software ERP SAP, membuat semua data yang ada diperusahaan dapat terintegrasi dengan baik untuk semua departemen, sehingga memudahkan management untuk memantu semua proses produksi maupun marketing, sehingga dapat mengambil keputusan yang cepat dan tepat. Software SAP memudahkan mampu telusur produk dari awal proses (bahan baku) sampai produk jadi (finish good).

Dengan slogan back to nature, peluang pemakaian herbal didunia meningkat, baik pasar domestik maupun internasional. Di pasar domestic, herbal mulai diterima di pelayanan kesehatan seperti puskesmas, klinik \& rumah sakit, sedangkan pasar internasional, penggunaan herbal semakin meningkat seperti di Amerika dan Eropa. Saat ini produk-produk borobudur telah diekspor ke beberapa negara seperti Rusia, Jepang, Amerika, Malaysia, Filipina, Saudi Arabia dll.

Untuk bisa bersaing di pasar global, perusahaan harus mempunyai strategi yang tepat, antara lain : penggunaan bahan baku (local content) yang tinggi, market oriented (bukan profit oriented), iklan (media cetak, televisi, maupun online), pameran, dan menerapkan sistem 5P (product, price, place, promotion \& personal).

Syarat utama agar Herbal dapat bersaing dan diterima di pasar internasional, maka produk herbal harus AMAN, BERMUTU DAN BERKHASIAT. 